\title{
Efficacy of fungicides against pathogens of apple core rot from the genera Fusarium Link, Alternaria Nees and Botrytis (Fr.) under laboratory conditions
}

\author{
Irina Astapchuk*, Galina Yakuba, and Andrei Nasonov \\ North Caucasian Federal Scientific Center of Horticulture, Viticulture, Wine-making, 39 str. 40 Let \\ Pobedy, Krasnodar, 350901, Russia
}

\begin{abstract}
As a result of the studies carried out, species-specific reactions of relative sensitivity to chemical fungicides of strains of the genera Fusarium Link, Alternaria Nees and Botrytis (Fr.) in vitro were noted. Fungicide Cidely-Top, DC inhibited the growth of fungi F. sporotrichioides, F. semitectum and A. alternata by $95-96 \%$, its minimum biological effectiveness was $83 \%$ on the $F$. oxysporum strain. Fungicide Luna Tranquility, SC showed very high antifungal activity against $F$. avenacium, $F$. oxysporum and A. alternata $(100 \%)$ and low antifungal activity against $F$. solani and B. cinerea (73-74 \%), other pathogens were suppressed with average activity. The drug Tirada, SC inhibited the growth of all studied micromycetes by $98-100 \%$, except for $B$. cinerea, the effectiveness against which was $94 \%$ and lower. In general, against the $B$. cinerea fungus, the effectiveness of all drugs was average or below average, which may indicate the presence of resistance in the studied strain.
\end{abstract}

\section{Introduction}

In fruit production, the apple tree ranks first, both in the North Caucasus region and in the world. A significant decrease in yield and product quality occurs, first of all, as a result of damage to fruits by mycoses. During the annual monitoring surveys of the gardens of the Krasnodar region, an increase in rotting of the core (seed cavity) of fruits caused by the pathocomplex of semi-parasitic fungi, among which the species of the genera Fusarim Link and Alternaria Nees predominate, was revealed [1-4].

Symptoms of the disease are most often found only when the fruit is cut. Infection of the apple tree even during the flowering period with the further, often asymptomatic, development of the disease makes it difficult to timely reject low-quality products. In recent years, there has been an increase in the harmfulness of the fungus Botrytis cinerea, which causes botrytis disease of apple fruits during storage, the yield loss from which can reach $24 \%$ in six months. In addition, this micromycete is part of the pathocomplex of fruit core rot [5]. The growth of harmfulness of the listed fungi requires the improvement of

\footnotetext{
* Corresponding author: irina_astapchuk@mail.ru
} 
protective measures to combat them. For this purpose, it is necessary to search for effective fungicides.

There is no single method for effective control of fungi of the genus Fusarium in different crops. Usually, the fight against pathogenic Fusarium species includes a set of measures - crop rotation, phytosanitary measures and the reasonable use of fungicides. Studies by V.V. Chekmarev et al. in laboratory conditions have established that the biological effectiveness of fungicides Abacus Ultra $(62.5 \mathrm{~g} / 1$ pyraclostrobin $+62.5 \mathrm{~g} / 1$ epoxiconazole), SE and Falcon $(250 \mathrm{~g} / 1$ spiroxamine $+167 \mathrm{~g} / 1$ tebuconazole $+43 \mathrm{~g} / \mathrm{l}$ triadimenol), EC for the fungus $F$. acuminatum Ellis \& Everh. (wheat) was low and amounted to 43.0-59.6\%, which may indicate the presence of resistance. The effectiveness of these agents against the fungus $F$. culmorum (Wm.G. Sm.) (wheat) was at a high level: 98.6-100\% [6-7]. A comparative assessment of the effectiveness of fungicides was given at four concentrations of the active substance $(10,100,1000$ and 10,000 parts per billion) containing pyraclostrobin (200 g / 1), thiram (400 g / 1), fludioxonil (25 g / 1), imazalil, metalaxil and tebuconazole $(50,40$ and $30 \mathrm{~g} / 1)$ for ten strains of Fusarium spp. (soy, barley, wheat, tomato). The most effective in suppressing the growth of fungi was found to be a pyraclostrobin-based fungicide; the sensitivity of $F$. acuminatum, $F$. graminearum Schwabe, F. semitectum, F. culmorum, F. sporotrichioides, $F$. equiseti strains to fungicides was higher than that of $F$. oxysporum, $F$. solani, $F$. verticillioides Sacc. and $F$. proliferatum [8].

At the same time, there is very little information in the literature on the effectiveness of chemicals used to protect fruit crops and grapes from a complex of pathogens of the genus Fusarium. So, the most effective chemical substances against strains of Fusarium fungi, which are the cause of infectious drying of the generative organs of grapes, in vitro experiments were: for $F$. proliferatum - thiram (chemical group of dithiocarbamates) + difenoconazole (triazoles), to a lesser extent - preparations containing methiram (dithiocarbamates) + pyraclostrobin (strobilurins); for $F$. oxysporum - difenoconazole, tetraconazole, difenoconazole + flutriafol (triazoles), as well as thiram + difenoconazole and mefentrifluconazole. From the group of strobilurins for $F$. proliferatum and F. oxysporum, preparations based on azoxystrobin are highly effective. For the same species, preparations of two active substances have shown high efficiency: fludioxonil (phenylpyrroles) + cyprodinil (anilinopyrimidines) [9].

In 2020, we assessed the biological effectiveness of chemical fungicides of various mechanisms of action - Chorus (750 g / kg cyprodinil), WDG; Luna Tranquility (125 g / 1 fluopyram + $375 \mathrm{~g} / 1$ pyrimethanil), SC; Granuflo ( $800 \mathrm{~g} / \mathrm{kg}$ thiram), WDG; Score (250 g $/ 1$ difenoconazole), EC for species $F$. avenaceum (Fr.) Sacc., F. solani (Mart.) Sacc. and F. semitectum Berk. \& Ravenel isolated from the seed cavity of infected apple fruits. Under in vitro conditions, a high (90-100\%) biological effectiveness of the studied drugs against $F$. avenaceum (Fr.) Sacc. Against the species $F$. solani and F. semitectum, the preparations Granuflo, WDG (17.3 and 17.8\%) and Luna Tranquility, SC (21.9 and 24.0\%) showed insufficient effectiveness, the active substances of which belong to the chemical groups dithiocarbamates and anilinopyrimidines, respectively. The studied species lacked sensitivity to Chorus, WDG (4.1 and $6.6 \%$ ). Fungicide Score, EC inhibited the growth of $F$. solani and F. semitectum by $72 \%$ [10]. Our earlier study of four fungicides of chemical origin Chorus, WDG, Luna Tranquility, SC, Granuflo, WDG, Score, CE for the species $F$. sporotrichioides and $F$. semitectum, causative agents of apple core rot, showed low biological effectiveness in two cultural characteristics. Its values, with one exception, did not exceed $50 \%$, and for some fungicides, in some indicators, there was no effectiveness. Species-specific reactions of relative sensitivity to chemical preparations according to different parameters in vitro were noted. Thus, F. semitectum showed a higher relative sensitivity in terms of the number of colonies, while F. sporotrichioides - in terms of the 
development of aerial mycelium [11]. We also studied the sensitivity to fungicides in vitro of another causative agent of rot of the core of apple fruits - Alternaria alternata (Fries: Fries) Keissler. The drug Luna Tranquility, SC showed an efficiency of $95 \%$, fungicide Granuflo, WDG - $70 \%$, Chorus, WDG - $75 \%$ [12]. In the studies of colleagues, 8hydroxyquinoline sulfate, kresoxim-methyl (analogs of strobilurins), had the greatest efficiency in suppressing the causative agent of A. tenuissima Wiltshire in vitro complex preparations of two active ingredients: difenoconazole + flutriafol, cyprodinil + iprodione (dicarboximides). Sufficient antifungal activity was demonstrated by fluopyram, difenoconazole, fludioxonil + cyprodinil at maximum concentrations; the smallest is a drug based on a mixture of thiram + difenoconazole [13Long-term data of colleagues [14-15] showed that preparations Score (250 g / L of difenoconazole), EC, Maxim (25 g / L of fludioxonil), SC, Zerox (3000 mg / L of colloidal silver), WS very effectively suppressed the growth and development of A. solani Sorauer, A. alternata, F. solani (potato, tomato); Preparation Prestige (140 g / 1 imidacloprid + 150 g / 1 pencycuron) SC showed high efficacy against Alternaria (A. solani) (potato, tomato). It was found that silver and copper suppress A. alternata (tomato) and Botrytis cinerea Pers. (strawberries) [16]. Studies of the in vitro fungicidal activity of thiazolidonones 1-4 [17], 1,2,3-triazolium-5-olates and 1,1,3trisubstituted triazenes [18] showed that these compounds have a selective antifungal effect against $B$. cinerea (cucumber). For the genus Botritis sp. (cobnut) the best fungicidal activity was exhibited by Klad, SC $(60 \mathrm{~g} / 1$ imazalil $+60 \mathrm{~g} / 1$ tebuconazole; $80 \mathrm{~g} / 1$ thiabendazole) [19].

It is not always possible to assess the effectiveness of chemical inhibition of a particular fungus species; in addition, many phytopathogens can acquire a certain level of resistance to fungicides. For this reason, it becomes necessary to study the effectiveness of drugs in relation to certain species using laboratory methods using pure cultures of fungi. The in vitro method allows in a fairly short time to assess the effectiveness of chemicals against pathogens [20-22].

Objective of the study: to determine the effectiveness of fungicides of chemical origin in vitro against some species of the genera Fusarium, Alternaria and Botritis, causative agents of rot of the apple fruits core.

\section{Materials and methods}

The studies were carried out in 2020 in the laboratory of biotechnological control of phytopathogens and phytophages of the FSBSI NCFSCHVW. The objects of research were monoconidial strains of apple core rot pathogens: Fusarium solani (strain FR20XXV / 1.2), Fusarium avenacium (strain FR20XXIV / 2.2.1), Fusarium sporotrichioides (strain FR20XXIV / 2.4), Fusarium oxysporum (strain FR20XXV / 2.4.1), Alternaria alternata (strain FR19I / 13.2), Botrytis cinerea (strain SR20 / 1).

The work studied the action of fungicides Cidely-Top, DC (125 g/l difenoconazole +15 $\mathrm{g} / \mathrm{l}$ ciflufenamide) and Tirada, CE (400 g / thiram $+30 \mathrm{~g} / \mathrm{l}$ difenoconazole). The control was distilled, autoclaved water; the standard was Luna Tranquility, SC (125 g/l fluopyram $+375 \mathrm{~g} / \mathrm{l}$ pyrimethanil). Solutions of fungicides were prepared from the calculation of the concentrations recommended by the manufacturer, according to the method of Chekmarev V.V. [19]. Aqueous solutions of the preparations were prepared on the day of the experiment and used fresh. In each Petri dish, $300 \mu \mathrm{L}$ of an aqueous solution of the drug or water was applied by two methods: they were evenly distributed with a sterile glass spatula over the surface of nutrient agar and by dropping onto three paper disks (for Tirada, EC, Luna Tranquility, SC), $1 \mathrm{~cm}$ in diameter, $100 \mu \mathrm{L}$ each for everyone.

The isolates of these species were inoculated with a small piece of aerial mycelium injected into the center of a Petri dish on a PGA medium (potato-glucose agar) in triplicate. 
The obtained crops were placed in a thermostat for 7 days and incubated at $25{ }^{\circ} \mathrm{C}$. All procedures related to manipulations with pure cultures were performed under sterile conditions.

The criterion for assessing the biological effectiveness (BE) of the preparations was the average growth rate $(\mathrm{cm})$ of the fungal colony (aerial mycelium), which was analyzed according to the generally accepted method [20]. Using the modified paper disk method $[13,23]$, the antifungal activity of the preparations was determined according to the scale:

0 points - no effect; 1 point - low activity; 2 points - average activity; 3 points - high activity; 4 points - very high activity.

This method makes it possible to assess the effect of the concentration gradient of the active substance on the growth of the fungal mycelium.

\section{Results and discussion}

The results obtained by various methods on the effectiveness of drugs against causative agents of rot of the core of apple fruits gave comparable data. So, with a uniform application of the drug to the agar surface, it was found that all the studied fungicides inhibited the growth of aerial mycelium of species of the genus Fusarium, but to varying degrees (Table 1, Figure 1). On the 7th day of fungi growth, the diameter of the culture ranged from $2.5 \mathrm{~cm}$ to $4.8 \mathrm{~cm}$. The highest sensitivity to all tested preparations was shown by $F$. sporotrichioides and $F$. avenacium, the lowest - by $F$. solani and $F$. semitectum.

Table 1. Influence of fungicides on the growth of fungi of the genus Fusarium in vitro, 7th day after inoculation

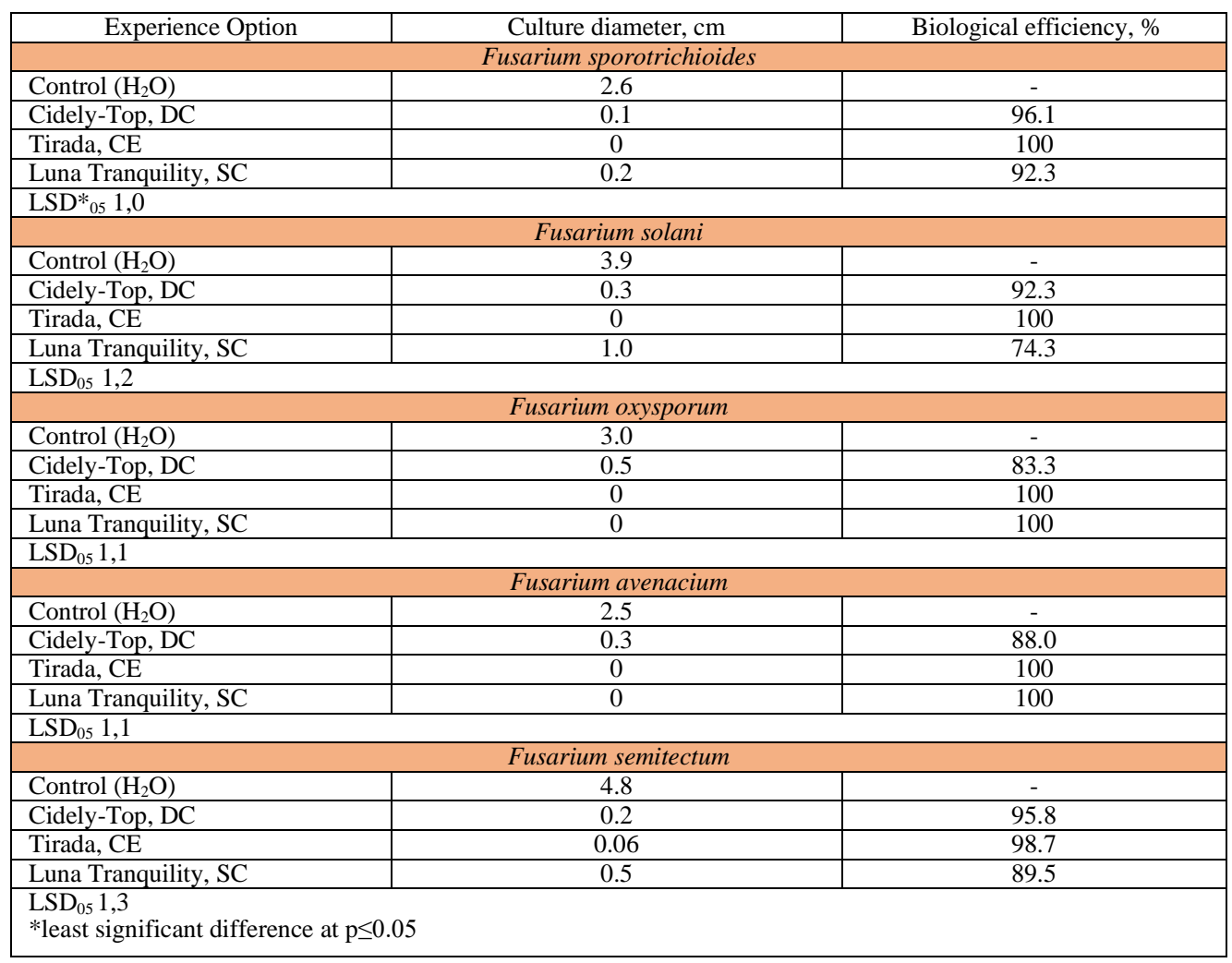




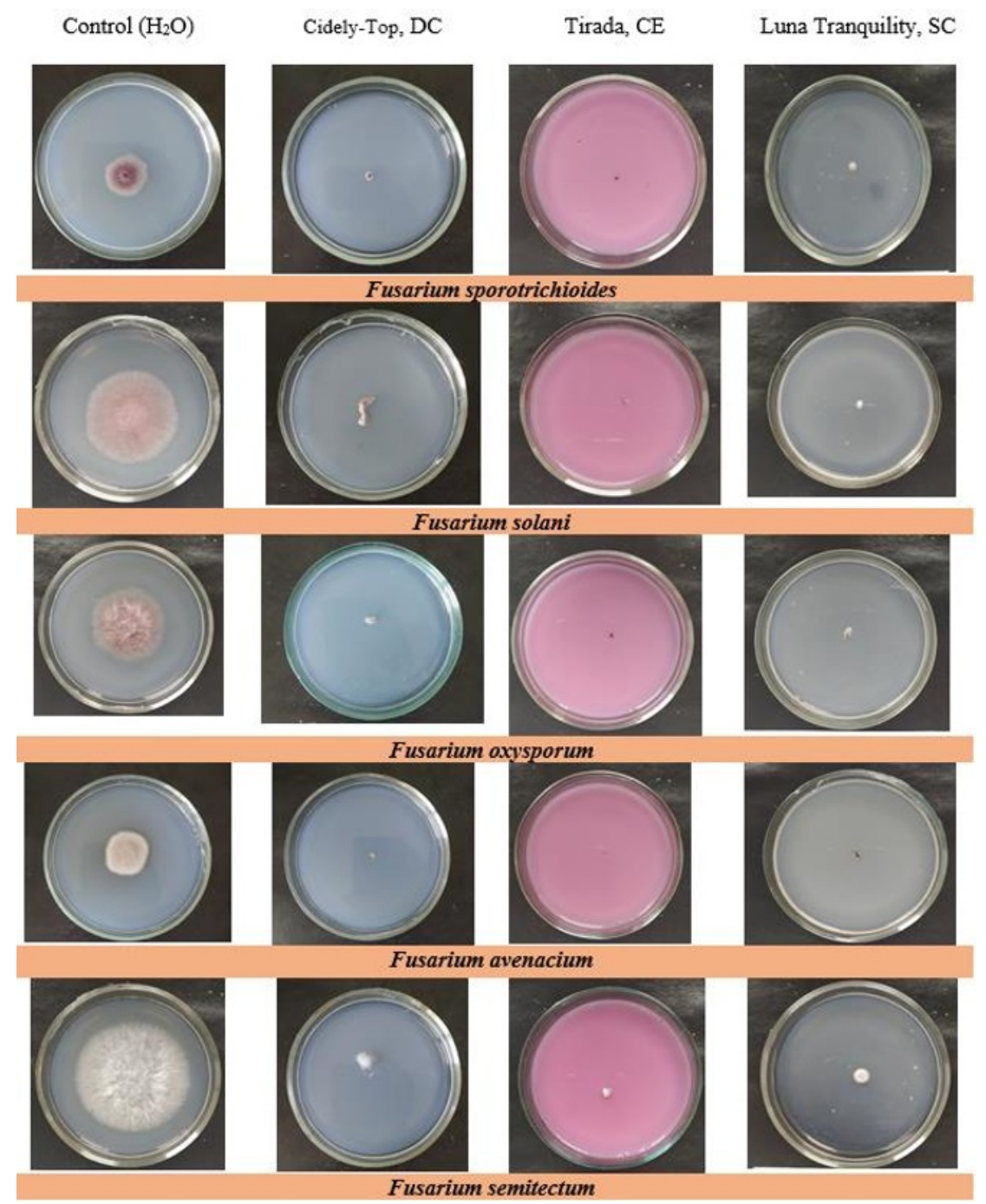

Fig. 1. The effect of drugs on the growth of fungi of the genus Fusarium in vitro, 7th day after inoculation

The maximum biological effectiveness of the fungicide Cidely-Top, DC was revealed for the fungi $F$. sporotrichioides (the most common species) and $F$. semitectum, the minimum for $F$. oxysporum and $F$. avenacium. The last two types of the drug Luna Tranquility, SC suppressed by $100 \%$, and showed minimal efficacy against the species $F$. solani. The drug Tirada, EC suppressed the growth of all studied micromycetes by $98-100 \%$, showing the best result.

Analysis of the biological effectiveness of fungicides against A. alternata in vitro revealed its high sensitivity to all drugs.

The B. cinerea strain turned out to be the fastest growing culture in this experiment and had the lowest sensitivity to all studied drugs (Table 2, Figure 2). 
Table 2. Influence of fungicides on the growth of fungi of the genus Alternaria and Botrytis in vitro, 7 th day after inoculation

\begin{tabular}{|c|c|c|}
\hline Experience Option & Culture diameter, $\mathrm{cm}$ & Biological efficiency, $\%$ \\
\hline \multicolumn{3}{|c|}{ Alternaria alternata } \\
\hline Control $\left(\mathrm{H}_{2} \mathrm{O}\right)$ & 3.0 & - \\
\hline Cidely-Top, DC & 0.1 & 96.6 \\
\hline Tirada, CE & 0 & 100 \\
\hline Luna Tranquility, SC & 0 & 100 \\
\hline \multicolumn{3}{|l|}{$\mathrm{LSD}_{05} 0,9$} \\
\hline \multicolumn{3}{|c|}{ Botrytis cinerea } \\
\hline Control $\left(\mathrm{H}_{2} \mathrm{O}\right)$ & 7.6 & - \\
\hline Cidely-Top, DC & 0.5 & 93.4 \\
\hline Tirada, CE & 0.4 & 94.7 \\
\hline Luna Tranquility, SC & 2.1 & 72.3 \\
\hline
\end{tabular}

Thus, having studied the biological effectiveness of three fungicides in vitro against pathogens of rot of the apple fruits core, it was found that drugs, where one of the active substances belongs to triazoles, suppressed the growth of pathogens of the genus Fusarium by $98-100 \%$, which coincides with the data of other researchers [13]. The efficacy of a preparation containing an active substance from the chemical group of anilinopyrimidines was found to be selective for the different species of this genus assessed. Thus, the effectiveness of Luna Tranquility, SC for strains $F$. solani and F. semitectum was lower. Earlier, we obtained similar results for F. solani [10].

The effectiveness of the preparations Tirada, EC and Luna Tranquility, SC in suppressing A. alternata was $100 \%$. For the preparation Luna Tranquility, SC, this result coincides with our previously obtained data [11]. At the same time, according to colleagues, the drug with the active substances thiram and difenoconazole showed lower values of effectiveness in the control of A. tenuissima, the causative agent of grape alternaria, in comparison with other studied drugs [13]. Differences in the results can be associated with both the characteristics of the strains and the emergence of resistance during long-term treatments. This work will be continued by us in the direction of expanding the number of studied strains, spectra of chemical groups of fungicides, as well as for other species of the genus Alternaria, causative agents of apple rot.

In relation to the $B$. cinerea fungus, the effectiveness of all drugs was average or below average, which indicates a low sensitivity of the studied strain. The chemical compounds were studied by us had a selective antifungal effect against this pathogen; the data obtained coincided with the results of colleagues [17-18]. For B. cinerea, the search for highly effective fungicides will continue, as well as the selection of the necessary concentrations in vitro.

In the analysis by the disk diffusion method, two preparations were evaluated, one of which contained a fungicide from the group of triazoles (Tirada, CE), and the other - aniline pyrimidines (Luna Tranquility, SC).

Using the paper disk method, it was also found that the preparations Tirada, CE and Luna Tranquility, SC had antifungal activity against the studied pathogens of apple core rot (Figures 3, 4, 5). Both drugs showed very high antifungal activity (4 points) against $\mathrm{F}$. oxysporum (LSD05 0.9) and medium (2 points) against B. cinerea (LSD05 1.2).

The fungicide Luna Tranquility, SC showed very high antifungal activity against the species F. avenacium (LSD05 0.9) and A. alternata (LSD05 0.7), and low for F. solani (1 point) (LSD05 1.0, the difference is insignificant); the drug suppressed other pathogens with medium activity ( 2 points). Fungicide Tirada, CE, on the contrary, for the pathogens $\mathrm{F}$. 
solani and F. sporotrichioides had the maximum antifungal activity (4 points) and for F. semitectum it was high (3 points).

Control $\left(\mathrm{H}_{2} \mathrm{O}\right)$
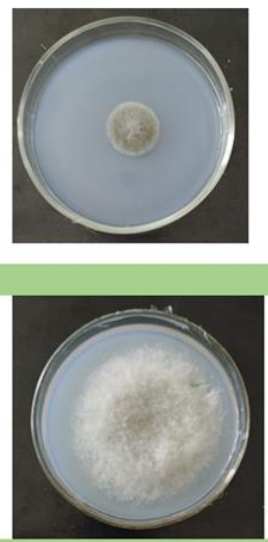

Cidely-Top, DC

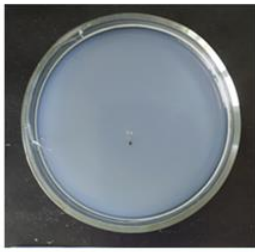

Alternaria alternata

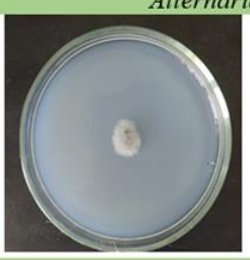

Botrytis cinerea
Tirada, CE Luna Tranquility, SC
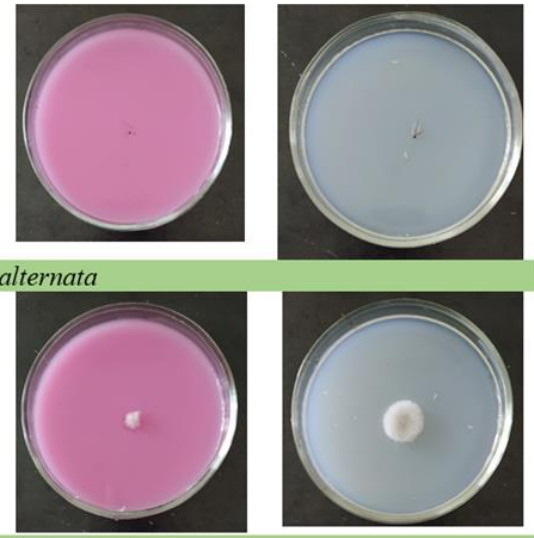

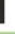

Fig. 2. The effect of drugs on the growth of fungi of the genus Alternaria and Botrytis in vitro, 7th day after inoculation

Thus, the disk diffusion method, as well as the method of uniform application of fungicides to the agar surface, showed a high efficiency of the preparation containing a compound from the triazole group as one of the active substances in relation to a larger number of pathogens. In this case, the drug Tirada, CE contains the second component, difenoconazole. This active ingredient is one of the most effective in the class of triazoles; proven to be effective against many fungi. For example, for the causative agent of apple scab, the fungicide remains highly effective after many years of use, and only isolated cases of a shift in sensitivity to it have been revealed [24]. It is noted that the resistance of triazoles is quantitative or dose-dependent, and the activity of difenoconazole against the same fungus is higher than other compounds [25].

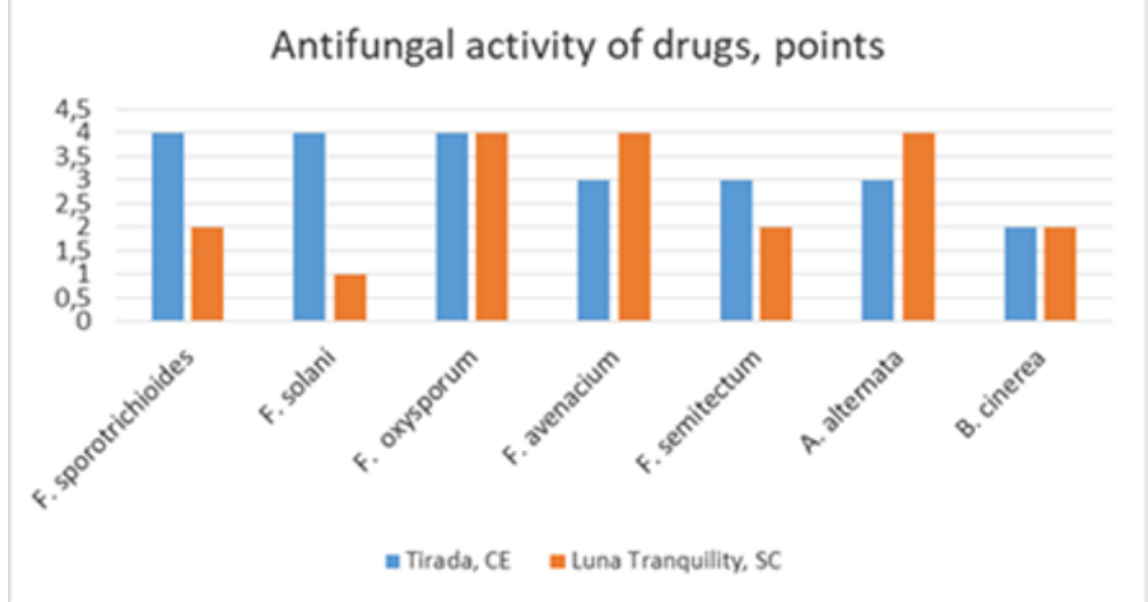

Fig. 3. Antifungal activity of the fungicides Tirada, $\mathrm{CE}$ and Luna Tranquility, SC against fungi of the genera Fusarium, Alternaria and Botrytis, causative agents of rot of the core of apple fruits, in vitro, 7 days after inoculation, paper disc method 


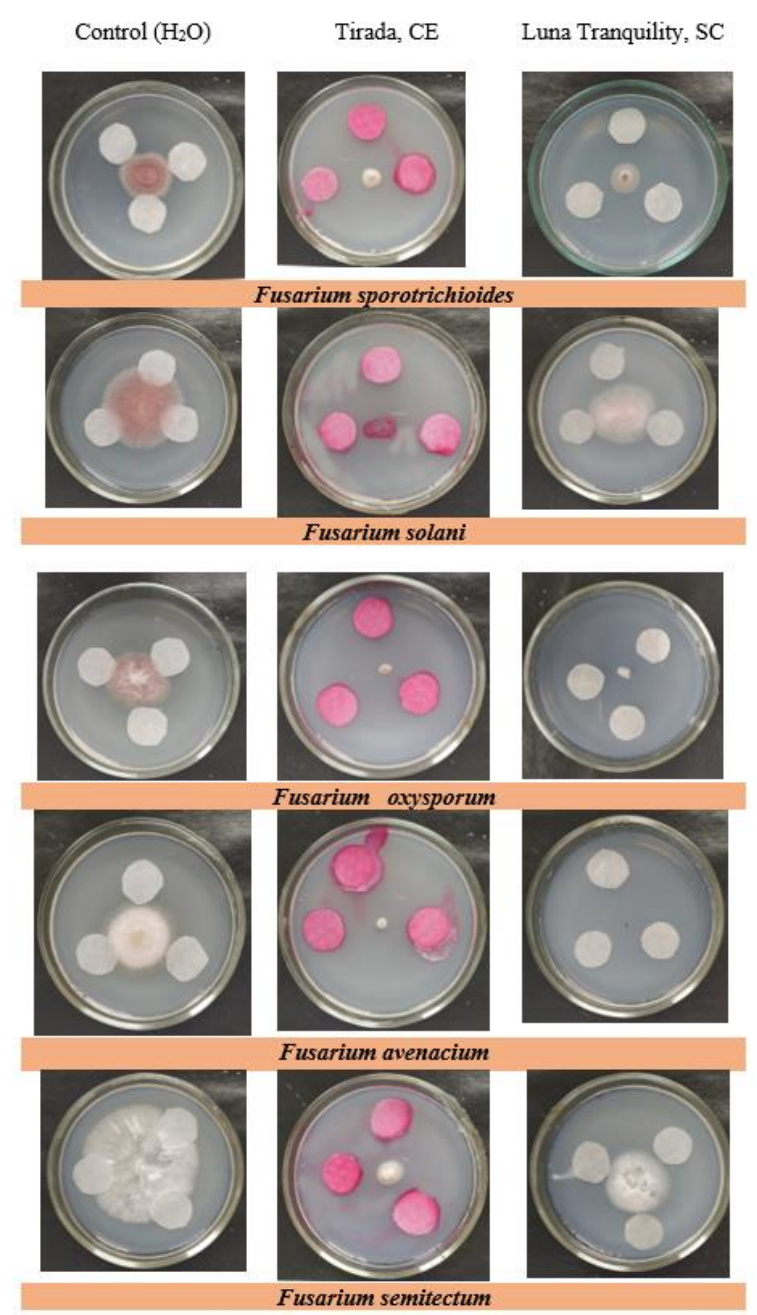

Fig. 4. The effect of drugs on the growth of fungi of the genus Fusarium in vitro, 7 th day after inoculation, paper disc method

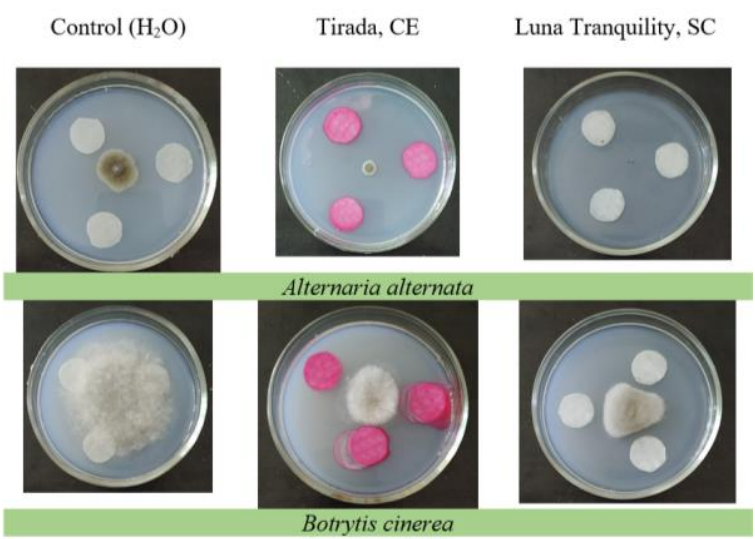

Fig. 5. The effect of drugs on the growth of fungi of the genus Alternaria and Botrytis in vitro, 7th day after inoculation, paper disk method 


\section{Conclusion}

As a result of the studies, species-specific reactions were noted regarding the sensitivity to chemical preparations of strains of the genera Fusarium, Alternaria and Botrytis under in vitro conditions. Fungicide Cidely-Top, DC inhibited the growth of fungi $F$. sporotrichioides, $F$. semitectum and A. alternata by $95-96 \%$, its minimal inhibition was 83 $\%$ on the $F$. oxysporum strain. Fungicide Luna Tranquility, SC showed very high antifungal activity against the species $F$. avenacium, $F$. oxysporum, and A. alternata (100\%) and low against $F$. solani and $B$. cinerea (BE 73-74 \%), suppressed other pathogens with an average activity. The drug Tirada, CE inhibited the growth of all studied micromycetes by 98-100 $\%$, except for B. cinerea, the effectiveness against which was $94 \%$ and lower. In general, against the fungus $B$. cinerea, the effectiveness of all drugs was average or below average, which may indicate a low sensitivity of this pathogen to the studied two-component fungicides.

A higher efficiency against a greater number of species of causative agents of rot of the apple fruits core was noted in preparations having a compound from the group of triazoles as one of the active substances.

\section{References}

1. S.E. Golovin Pomiculture and small fruits culture in Russia, 30, 328-337 (2012) https://www.elibrary.ru/download/elibrary_17769996_86984994.pdf

2. S. Türkölmez, S. Dervis Plant Protect. Sci., 53 (4). 216-225. (2017) https://doi.org/10.17221/38/2016-PPS

3. M. Mazzola, J. Brown. Replant Disease in Conventional and Organic Production Systems. Plant Dis, 94, 835-842 (2010) http://doi.org/10.1094/PDIS-94-7-0835

4. X.R. Chen, S.X. Huang, Y. Zhang, G.-L. Sheng, B.Y. Zhang, Q.Y. Li, F. Zhu, J.Y. Xu Mol Genet Genomics, 293, 541-555 (2018) https://doi.org/10.1007/s00438-017-1400-7

5. G.V. Yakuba Zashchita i karantin rastenij, 8, 37-39. https://www.elibrary.ru/download/elibrary_29879957_33899056.pdf

6. V.V. Chekmarev, N.N. Dubrovskaya, O.I. Korabel'skaya, I.V. Gusev, G.N. Buchneva, Sbornik statej XXII mezhdunarodnoj nauchno-prakticheskoj konferencii, 16-17 (2019) https://www.elibrary.ru/download/elibrary_39148835_77187936.pdf

7. V.V. Chekmarev, The Scientific Heritage, 51-1, 17-19 (2020) https://www.elibrary.ru/download/elibrary_44025066_96915261.pdf

8. A. Orina, O. Gavrilova, T. Gagkaeva, The effect of fungicides on growth of Fusarium fungi in vitro January 2020BIO Web of Conferences 18:00022 https://www.researchgate.net/publication/339745317_The_effect_of_fungicides_on_gro wth_of_Fusarium_fungi_in_vitro

9. N.V. Savchuk, E.G. Yurchenko Materialy IX Mezhdunarodnoj nauchno-prakticheskoj konferencii «Zashchita rastenij ot vrednyh organizmov», 232-233 (2019) https://www.elibrary.ru/download/elibrary_41331871_14509560.pdf

10. G.V. Yakuba, I.L. Astapchuk, A.I. Nasonov Tavricheskij vestnik agrarnoj nauki, 2 (22), 188-197 (2020) https://www.elibrary.ru/download/elibrary_43418287_80372598.pdf

11. G.V. Yakuba, I.L. Astapchuk, A.I. Nasonov, Sovremennoe sostoyanie, problemy i perspektivy razvitiya agrarnoj nauki, $106-108$ (2020) https://www.elibrary.ru/download/elibrary_44115358_59042642.pdf

12. G.V. Yakuba, I.L. Astapchuk, Plants and microorganisms: future biotechnology, 280. (2020) https://www.elibrary.ru/item.asp?id=44256883 
13. M.V. Burovinskaya, E.G. Yurchenko, Plodovodstvo i vinogradarstvo Yuga Rossii, 58 (4), 146-165 https://www.elibrary.ru/download/elibrary_38583910_85148904.pdf

14. E.D. Myca, S.N. Elanskij, L.YU. Kokaeva, M.A. Pobedinskaya, A.N. Ignatov, M.A. Kuznecova, B.E. Kozlovskij, A.N. Denisov, P.M. ZHerebin, YU.A. Krutyakov, $\begin{array}{llllll}\text { Dostizheniya nauki i tekhniki APK, 12, } & 16-19 \quad \text { (2014) }\end{array}$ https://www.elibrary.ru/download/elibrary_22776122_40714700.pdf

15.E.D. Myca, Avtoreferat disc. ... kandidata biologicheskih nauk (2015) https://dlib.rsl.ru/viewer/01005560737\#?page=1

16. M. Ouda Sahar, Research Journal of Microbiology, 9 (1), 34-42 (2014) https://www.researchgate.net/publication/276044149_Antifungal_Activity_of_Silver_a nd_Copper_Nanoparticles_on_Two_Plant_Pathogens_Alternaria_alternata_and_Botryti s_cinerea

17. A.A. Kotlovanov, K.L. Obydennov, T.A. Kalinina, O.A. Vysokova, A.N. Galushchinskij, T.V. Gluhareva, Sovremennye podhody i metody v zashchite rastenij 25-27 (2018) https://elar.urfu.ru/handle/10995/66377

18. A.P. Muhametkulova, K.M. Hasanova, T.A. Kalinina, O.A. Vysokova, YU.I. Nejn, T.V. Gluhareva, Sovremennye podhody i metody v zashchite rastenij 49-51, (2018) https://elar.urfu.ru/handle/10995/66377

19. R.S. Rahmangulov, N.A. Urazbahtina, T.A. Simonyan, A.O. Mac'kiv, G.A. Caturyan, Novye tekhnologii, 4, 191-199 (2019) https://www.elibrary.ru/download/elibrary_42463041_66071145.pdf

20. V.V. Chekmarev, Metodika opredeleniya biologicheskoj effektivnosti fungicidov v otnoshenii gribov roda Fusarium i ih rezistentnosti k himicheskim preparatam, (2015) https://www.elibrary.ru/download/elibrary_35307475_46783273.pdf

21. N.N. Dubrovskaya, I.V. Gusev, V.V. Chekmarev, Fundamental'nye nauchnye issledovaniya: teoreticheskie i prakticheskie, 215-217 (2018) https://www.elibrary.ru/download/elibrary_32831507_23955056.pdf

22. V.V. Chekmarev, N.N. Dubrovskaya, O.I. Korabel'skaya, G.N. Buchneva, Zernovoe $\begin{array}{lllll}\text { hozyajstvo } & \text { Rossii } & 5 & \mathbf{5 3}), & 65-68 .\end{array}$ https://www.elibrary.ru/download/elibrary_32257658_47984902.pdf

23. O.M. Minaeva, E.E. Akimova, T.I. Zyubanova, N.N. Tereshchenko, Biopreparaty dlya zashchity rastenij: ocenka kachestva i effektivnosti (2018) https://core.ac.uk/reader/287420250

24.E.V. Lobodina, I.L. Astapchuk, A.I. Nasonov, Nauchnye trudy Severo-Kavkazskogo federal'nogo nauchnogo centra sadovodstva, vinogradarstva, vinodeliya, 26, 165-169. (2019) https://elibrary.ru/download/elibrary_41375353_72934853.pdf

25. K.D. Cox, Fungicide Resistance in Plant Pathogens. Tokyo: Springer, 433-447. (2015) https://doi.org/10.1007/978-4-431-55642-8_27 